\title{
The Effect of Racemic, D-, or I-Propranolol and Practolol on the Response to Cold by the Newborn Rabbit
}

\author{
I. DOBER ${ }^{(25)}$ AND V. JASZAI \\ Department of Paediatrics, University of Pecs, Pecs, Hungary \\ T. HEIM \\ Department of Paediatrics, University of Toronto, Toronto, Canada \\ R. D. G. MILNER \\ Department of Paediatrics, University of Sheffield, Sheffield, England
}

\begin{abstract}
Summary
The newborn rabbit has been used as a model to investigate the effects of propranolol, the isomers of propranolol, and practolol on the response to cold exposure. Racemic propranolol $(1 \mathrm{mg} / \mathrm{kg})$ caused a significant drop in oxygen consumption and higher doses ( 2.25 and $5.0 \mathrm{mg} / \mathrm{kg}$ ) abolished the rise caused by cold exposure (Table 1). This effect was not mimicked consistently by either the D or I isomer. Practolol had no significant effect at a $1.0 \mathrm{mg} / \mathrm{kg}$ dose but in the doses of 2.25 and $5.0 \mathrm{mg} / \mathrm{kg}$ completely blocked the cold-induced rise of oxygen consumption. Racemic propranolol caused an increased fall in colonic temperature which was significant when $2.25 \mathrm{mg} / \mathrm{kg}$ was used. Neither of the two propranolol isomers nor practolol had a significant effect on colonic temperature (Table 2). In contrast, both 2.25 and $5.0 \mathrm{mg} / \mathrm{kg}$ racemic propranolol and $2.25 \mathrm{mg} / \mathrm{kg}$ practolol caused a significantly greater drop in brown fat temperature than that caused by exposure to $25^{\circ}$. The isomers of propranolol did not affect brown fat temperature significantly (Table 3 ). The rise in serum free fatty acid (FFA) concentration induced by cold exposure was reduced or abolished by each drug in every dose used (Table 4). The rise in blood glucose due to cold was abolished by racemic propranolol and practolol in all doses used (Table 5). I-Propranolol significantly inhibited the rise in blood glucose from $60-90 \mathrm{~min}$ and caused a fall below the levels seen at $60 \mathrm{~min}$. D-Propranolol had no effect on blood glucose levels. The results show that the $\beta$ blockers, propranolol and practolol, seriously compromise the response of the newborn rabbit to thermal stress.
\end{abstract}

\section{Speculation}

Perinatal exposure to $\beta$ blockers may compromise the metabolic response of the newborn infant to cold exposure. The mechanism of action of propranolol in this respect is not explained by the sum of the actions of its isomers.

Drugs acting on $\beta$ adrenoreceptors are now commonly used in clinical obstetric practice $(15,16)$. The indications are most commonly to stimulate or inhibit uterine contractions but $\beta$ blockers are also employed for their effect on the maternal cardiovascular system. The sheep placenta is permeable to propranolol and other $\beta$ blockers (20) and the human placenta is probably permeable to $\beta$ blockers $(1,4)$. Despite this knowledge that the fetus may be acutely or chronically exposed to such drugs there is little information on the effect of these drugs on the newborn. A case report has suggested that chronic fetal exposure to propranolol may have affected growth as well as having cardiovascular effects (18).

Interest in drugs acting on adrenergic receptors of adipose tissue in the rabbit stems from the work of Hull (13), who showed that although pronethalol blocked lipolysis stimulated by isoprenaline or noradrenaline, it was ineffective against cold-induced lipolysis. Subsequently, the role of propranolol in neonatal metabolic homeostasis has been studied in animals $(2,7)$ and clinically $(8)$. In the present study we have sought to extend and integrate earlier observations of $\beta$ blockers on the calorigenic and metabolic response to cold exposure. The results show that both propranolol and practolol seriously compromise the response of the neonate to thermal stress. A preliminary account of part of the work has been published $(10,12)$.

\section{MATERIALS AND METHODS}

\section{EXPERIMENTAL DESIGN}

In all experiments rabbit pups of Dutch stock, 3-7 days of age, were used. The animals were with the mother from birth until 1 $\mathrm{hr}$ before the experiment when they were isolated and kept in a thermoneutral environment of $35^{\circ}$. In one kind of experiment oxygen consumption and colonic and interscapular brown fat temperature were measured. The animal was placed on a wire grid a few millimeters above the floor in a chamber connected to a closed circuit which included a circulating pump (air flow 2-3 liters/min) and a soda-lime cannister to absorb carbon dioxide and to which oxygen was added to maintain a constant volume and pressure. The characteristics of the circuit have been reported previously in detail $(9,19)$. The chamber was placed in a water bath the temperature of which was controlled to within $0.1^{\circ}$. Colonic and brown fat temperatures were measured by fine copper-constantan thermocouples (diameter $1 \mathrm{~mm}$, internal resistance $100 \mathrm{ohm}$ ) which were inserted $3-5 \mathrm{~cm}$ above the anus or placed sc above the interscapular brown adipose tissue. Oxygen consumption and temperature were registered every $2 \mathrm{~min}$ and readings taken from the mean of the last $10 \mathrm{~min}$ of a 30 -min period before a change in experimental condition were used. At this time the measurements were reproducible. The oxygen consumption was corrected to STPD (standard temperature, pressure dry). Readings were made after $30 \mathrm{~min}$ at thermoneutrality $\left(\mathrm{Ta} 35^{\circ}\right.$ ) then after 30 min in a cold environment $\left(\mathrm{Ta} 25^{\circ}\right)$. At this point the animal was given an ip injection of a drug and a final reading was made after a further $30 \mathrm{~min}$ at $25^{\circ}$. The drugs used were racemic, D-, or L- 
propranolol and practolol (22) in doses of $1.0,2.25$, and $5.0 \mathrm{mg} / \mathrm{kg}$. The drugs were dissolved in physiologic saline and control animals received saline injections alone. Two types of control experiment were performed. In one the animals were treated exactly as the drug-injected group but were given a saline injection (cold-exposed group), in the other the animals received a saline injection but the chamber temperature was kept at $35^{\circ}$ throughout (thermoneutral control group).

In the second type of experiment the animals were anesthetized with ether and the carotid artery was cannulated. The animal was then kept in an open nest, the temperature of which was maintained by a radiant heater at $35^{\circ}$ for $30 \mathrm{~min}$. The ambient temperature was then changed to $25^{\circ}$ by switching off the radiant heater and switching on a thermocontrolled fan which blew air over the nest for $30 \mathrm{~min}$, after which the animal received an ip injection of one of the drugs or saline, before being returned to the $25^{\circ}$ environment for a final $30 \mathrm{~min}$. Blood samples (approximately $0.2 \mathrm{ml}$ ) were collected from the cannula into glass capil- laries at the time of cannulation $(0 \mathrm{~min})$ and after 30,60 , and 90 min. Immediately after the final sample was collected the animal was killed by decapitation and mixed arterial and venous blood was collected from the neck vessels. The patency of the cannula was maintained by filling the dead space with physiologic saline. Blood glucose concentration was estimated by the method of Hultman (14) and serum FFA concentration by the method of Novak (17)

\section{STATISTICAL ANALYSIS}

In both types of experiment sequential measurements were made on the same animal at 30,60 , and $90 \mathrm{~min}$. All results were therefore analyzed for the purposes of comparison between groups as the mean change taking place between 30 and 90 min (effect of temperature change \pm drug), and between 60 and 90 min (effect of the drug). Differences in these changes were compared statistically using Student's $t$-test.

Table 1. Oxygen consumption ( $\left.\mathrm{ml} / \mathrm{kg} \mathrm{min}^{-1}\right)$ by 3-to 7-day-old rabbits nursed at $35^{\circ}$ or $25^{\circ}$ and treated with racemic, $\mathrm{D}^{-}$, or L-propranolol or practolol ${ }^{1}$

\begin{tabular}{|c|c|c|c|c|c|}
\hline & $n$ & $60 \mathrm{~min}$ & $90 \mathrm{~min}$ & $(90-30) \min$ & $(90-60) \min$ \\
\hline Thermoneutral control 7 & 7 & $18.1 \pm 0.5^{2}$ & $18.2 \pm 0.5^{2}$ & $0.0 \pm 0.1$ & $+0.1 \pm 0.1$ \\
\hline Cold control & 7 & $31.5 \pm 3.7^{3}$ & $31.7 \pm 3.7^{3}$ & $+12.8 \pm 3.4$ & $+0.2 \pm 0.1$ \\
\hline \multicolumn{6}{|l|}{ Racemic propranolol } \\
\hline $1.0 \mathrm{mg} / \mathrm{kg}$ & 11 & $36.7 \pm 2.1^{3}$ & $28.0 \pm 2.8^{3}$ & $+9.8 \pm 2.8^{4}$ & $-8.7 \pm 1.7^{4}$ \\
\hline $2.25 \mathrm{mg} / \mathrm{kg}$ & 6 & $44.7 \pm 1.5^{3}$ & $15.6 \pm 2.2^{3}$ & $-0.3 \pm 2.2^{4}$ & $-29.1 \pm 3.1^{4}$ \\
\hline $5.0 \mathrm{mg} / \mathrm{kg}$ & 5 & $41.1 \pm 1.3^{3}$ & $14.3 \pm 0.5^{3}$ & $-1.8 \pm 0.5^{4}$ & $-26.8 \pm 1.4^{4}$ \\
\hline \multicolumn{6}{|l|}{ L-Propranolol } \\
\hline $1.0 \mathrm{mg} / \mathrm{kg}$ & 7 & $32.3 \pm 1.7^{3}$ & $27.9 \pm 3.7^{3}$ & $+9.9 \pm 3.7$ & $-4.3 \pm 3.7$ \\
\hline $2.25 \mathrm{mg} / \mathrm{kg}$ & 7 & $33.4 \pm 3.6^{3}$ & $20.8 \pm 3.3^{3}$ & $+2.6 \pm 3.4$ & $-12.6 \pm 2.8^{4}$ \\
\hline $5.0 \mathrm{mg} / \mathrm{kg}$ & 6 & $33.3 \pm 3.3^{3}$ & $30.1 \pm 4.2^{3}$ & $+12.5 \pm 4.1$ & $-3.2 \pm 1.7$ \\
\hline \multicolumn{6}{|l|}{ D-Propranolol } \\
\hline $1.0 \mathrm{mg} / \mathrm{kg}$ & 5 & $41.3 \pm 5.4^{3}$ & $37.7 \pm 5.2^{3}$ & $+20.2 \pm 4.5$ & $-3.6 \pm 1.6$ \\
\hline $2.25 \mathrm{mg} / \mathrm{kg}$ & 5 & $39.4 \pm 1.0^{3}$ & $33.8 \pm 3.0^{3}$ & $+16.4 \pm 3.4$ & $-5.6 \pm 3.6$ \\
\hline $5.0 \mathrm{mg} / \mathrm{kg}$ & 6 & $37.7 \pm 1.1^{3}$ & $32.6 \pm 2.7^{3}$ & $+15.6 \pm 2.6$ & $-5.1 \pm 2.7$ \\
\hline \multicolumn{6}{|l|}{ Practolol } \\
\hline $1.0 \mathrm{mg} / \mathrm{kg}$ & 5 & $36.1 \pm 1.3^{3}$ & $33.5 \pm 0.3^{3}$ & $+20.4 \pm 0.1$ & $-2.6 \pm 1.0$ \\
\hline 2.25 & 5 & $45.0 \pm 3.2^{3}$ & $12.8 \pm 0.4^{3}$ & $-4.1 \pm 0.4^{4}$ & $-32.2 \pm 3.6^{4}$ \\
\hline $5.0 \mathrm{mg} / \mathrm{kg}$ & 5 & $43.3 \pm 1.0^{3}$ & $17.1 \pm 1.2^{3}$ & $-0.1 \pm 1.2^{4}$ & $-26.2 \pm 1.7^{4}$ \\
\hline
\end{tabular}

${ }^{1}$ Results are expressed as mean \pm SEM. The drug was injected ip at $60 \mathrm{~min}$.

${ }^{2}$ Ambient temperature $35^{\circ}$.

${ }^{3}$ Ambient temperature $25^{\circ}$

${ }^{4}$ Level of significance compared with cold control: $P<0.01$ or greater.

Table 2. Colonic temperature $\left({ }^{\circ} \mathrm{C}\right)$ of 3-to 7-day-old rabbits nursed at $35^{\circ}$ or $25^{\circ}$ and treated with racemic, D-, or L-propranolol, or practolol $^{1}$

\begin{tabular}{|c|c|c|c|c|c|}
\hline & $n$ & $60 \mathrm{~min}$ & $90 \mathrm{~min}$ & $(90-30) \min$ & $(90-60) \mathrm{min}$ \\
\hline Thermoneutral control & 9 & $36.59 \pm 0.1^{2}$ & $36.6 \pm 0.1^{2}$ & $0 \pm 0.02$ & $0.01 \pm 0.02$ \\
\hline Cold control & 8 & $34.5 \pm 0.1^{2}$ & $31.7 \pm 0.3^{3}$ & $-5.8 \pm 0.4$ & $-2.8 \pm 0.3$ \\
\hline \multicolumn{6}{|l|}{ Racemic propranolol } \\
\hline $2.25 \mathrm{mg} / \mathrm{kg}$ & 6 & $34.2 \pm 1.3^{3}$ & $29.8 \pm 1.2^{3}$ & $-8.1 \pm 1.0$ & $-4.4 \pm 0.5^{4}$ \\
\hline $5.0 \mathrm{mg} / \mathrm{kg}$ & 5 & $34.9 \pm 0.5^{3}$ & $31.2 \pm 1.1^{3}$ & $-7.3 \pm 1.2$ & $-3.8 \pm 0.7$ \\
\hline \multicolumn{6}{|l|}{ L-Propranolol } \\
\hline $1.0 \mathrm{mg} / \mathrm{kg}$ & 7 & $33.8 \pm 0.5^{3}$ & $32.01 \pm 0.5^{3}$ & $-5.6 \pm 0.4$ & $-1.8 \pm 0.3$ \\
\hline $2.25 \mathrm{mg} / \mathrm{kg}$ & 7 & $33.6 \pm 0.3^{3}$ & $31.8 \pm 0.2^{3}$ & $-5.3 \pm 0.3$ & $-1.9 \pm 0.1$ \\
\hline $5.0 \mathrm{mg} / \mathrm{kg}$ & 7 & $33.7 \pm 0.4^{3}$ & $31.7 \pm 0.3^{3}$ & $-6.0 \pm 0.4$ & $-2.0 \pm 0.5$ \\
\hline \multicolumn{6}{|l|}{ D-Propranolol } \\
\hline $2.25 \mathrm{mg} / \mathrm{kg}$ & 7 & $35.0 \pm 0.4^{3}$ & $33.0 \pm 0.5^{3}$ & $-4.8 \pm 0.6$ & $-2.0 \pm 0.3$ \\
\hline $5.0 \mathrm{mg} / \mathrm{kg}$ & 6 & $35.0 \pm 0.9^{3}$ & $32.4 \pm 0.7^{3}$ & $-5.8 \pm 0.8$ & $-2.7 \pm 0.7$ \\
\hline \multicolumn{6}{|l|}{ Practolol } \\
\hline $2.25 \mathrm{mg} / \mathrm{kg}$ & 5 & $32.8 \pm 1.0^{3}$ & $29.8 \pm 0.4^{3}$ & $-7.8 \pm 0.6$ & $-3.1 \pm 0.7$ \\
\hline $5.0 \mathrm{mg} / \mathrm{kg}$ & 5 & $33.2 \pm 0.6^{3}$ & $32.0 \pm 0.5^{3}$ & $-6.2 \pm 0.6$ & $-1.2 \pm 0.5$ \\
\hline
\end{tabular}

${ }^{1}$ Results are expressed as mean \pm SEM. The drug was injected ip at $60 \mathrm{~min}$.

${ }^{2}$ Ambient temperature $35^{\circ}$.

${ }^{3}$ Ambient temperature $25^{\circ}$.

${ }^{4}$ Level of significance compared with cold control: $P<0.05$. 


\section{RESULTS}

Eighty-nine animals were used for the experiments in which oxygen consumption, colonic, and brown fat temperature were measured. Their mean $( \pm \mathrm{SD})$ body weight was $95.6 \pm 19.8 \mathrm{~g}$. No correlation was observed between body weight and any of the measurements made.

\section{OXYGEN CONSUMPTION}

The mean $( \pm \mathrm{SD})$ oxygen consumption of all the pups after exposure to $35^{\circ}$ for $30 \mathrm{~min}$ was $17.4 \pm 2.6 \mathrm{ml} / \mathrm{kg} \mathrm{min}^{-1}$ and the range of mean values between different groups was 13.1-18.9 $\mathrm{ml} / \mathrm{kg} \mathrm{min}^{-1}$. The thermoneutral control group nursed at the same temperature for two further 30 -min periods showed no change in oxygen consumption, indicating that the initial measurement was representative of basal conditions and that an ip injection of saline had no effect on oxygen consumption (Table 1), either in the thermoneutral $\left(\mathrm{Ta} 35^{\circ}\right)$ or cold $\left(\mathrm{Ta} 25^{\circ}\right)$ environment.
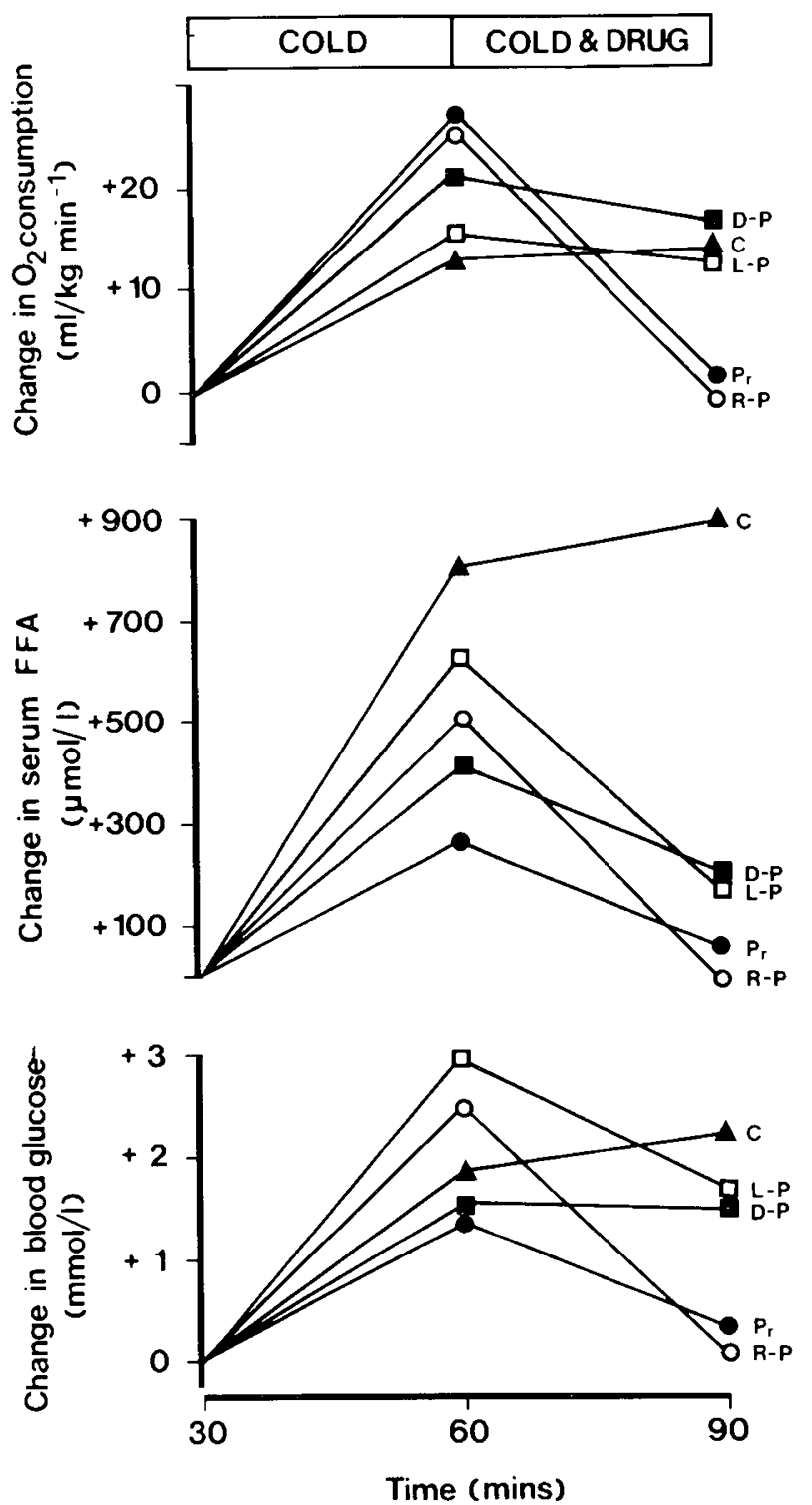

Fig. 1. Change in mean level of oxygen consumption, serum FFA and glucose concentration in 3- to 7-day old rabbits nursed at $25^{\circ}$ from $30-90$ $\mathrm{min}$ and given $\beta$-blocker drugs ( $5 \mathrm{mg} / \mathrm{kg}$ ip) at $60 \mathrm{~min}$. C: control animals (O), R-P: racemic propranolol (峁, D-P: D-propranolol (W), L-P: L-pro-

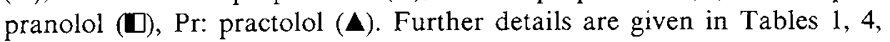
and 5 .
The mean oxygen consumption of different groups after exposure to $25^{\circ}$ for $30 \mathrm{~min}$ varied, the range being $31.5-45.0 \mathrm{ml} / \mathrm{kg}$ $\min ^{-1}$, but a second $30 \mathrm{~min}$ at $25^{\circ}$ in the cold control group produced no further rise of oxygen consumption.

Racemic propranolol ( $1 \mathrm{mg} / \mathrm{kg}$ ) caused a significant drop in oxygen consumption and higher doses $(2.25$ and $5.0 \mathrm{mg} / \mathrm{kg})$ abolished the rise caused by cold exposure (Table 1). This effect was not mimicked consistently by either the $\mathrm{D}$ or $\mathrm{L}$ isomer, although $2.25 \mathrm{mg} / \mathrm{kg}$ L-propranolol did cause a significant inhibition of cold-stimulated oxygen consumption. Practolol had no significant effect at a $1.0 \mathrm{mg} / \mathrm{kg}$ dose, but in the doses of 2.25 and $5.0 \mathrm{mg} / \mathrm{kg}$ completely blocked the cold-induced rise of oxygen consumption.

\section{COLONIC AND BROWN FAT TEMPERATURE}

In the 70 pups used for the measurement of body temperature the mean $( \pm \mathrm{SD})$ colonic and brown fat temperatures after $30 \mathrm{~min}$ at $35^{\circ}$ were $37.6 \pm 0.7^{\circ}$ and $37.3 \pm 0.8^{\circ}$, respectively. No change in body temperature occurred in the thermoneutral group in the next two 30-min periods from 30-90 min. In the cold control group there was a progressive fall in both colonic and brown fat temperature on exposure to $25^{\circ}$ (Tables 2 and 3). After $1 \mathrm{hr}$ at $25^{\circ}$ the mean $( \pm \mathrm{SEM})$ brown fat temperature was $+1.5 \pm 0.4^{\circ}$ higher than that in the colon $(n=8, P<0.01)$, indicating a vigorous calorigenesis in this adipose organ, whereas in the thermoneutral control group maintained at $35^{\circ}$ the difference was $-0.3 \pm 0.1^{\circ}$ $(n=7, P<0.01)$.

Racemic propranolol caused an increased fall in colonic temperature which was significant when $2.25 \mathrm{mg} / \mathrm{kg}$ was used. Neither of the two propranolol isomers nor practolol had a significant effect on colonic temperature. In contrast, both 2.25 and 5.0 $\mathrm{mg} / \mathrm{kg}$ racemic propranolol and $2.25 \mathrm{mg} / \mathrm{kg}$ practolol caused a significantly greater drop in brown fat temperature than that caused by exposure to $25^{\circ}$. The isomers of propranolol did not affect brown fat temperature signifiantly.

\section{SERUM FFA}

The 142 animals used for the measurement of glucose and free fatty concentration had a mean $( \pm \mathrm{SD})$ body weight of $93.7 \pm 16.6$ $\mathrm{g}$, which was similar to that of those used in the first series of experiments. No association between body weight and the initial circulating levels of FFA or glucose or the response to experimental manipulation was observed.

At the time of cannulation the mean $( \pm \mathrm{SD})$ serum FFA concentration was $763 \pm 198 \mu \mathrm{mol} /$ liter, but during the next $30 \mathrm{~min}$ no significant change occurred: $+12 \pm 15 \mu \mathrm{mol} /$ liter $(n=18)$. The mean $( \pm \mathrm{SD})$ serum FFA concentration of all 142 animals after 30 $\min$ at $35^{\circ}$ was $619 \pm 252 \mu \mathrm{mol} /$ liter, indicating the wide variation in this metabolite which occurred presumably as a result of anesthesia and the cannulation procedure. In the theoneutral control animals there was a further but insignificant increase in the next two 30-min periods, which contrasted with a dramatic doubling of serum FFA concentration in the cold controls when exposed to $25^{\circ}$ for $30 \mathrm{~min}$ (Table 4). From 60-90 min there was a further small but significant increase in serum FFA in this group.

The rise in serum FFA concentration induced by cold exposure was reduced or abolished by each drug in every dose used. This conclusion is based on the change occurring between 60 and 90 min and caution must be exercised in the analysis of changes occurring between 30 and 90 min since the mean $( \pm$ SEM) rise of FFA levels in the cold control group on initial exposure to $25^{\circ}$ (30-60 min) was $+812 \pm 112 \mu \mathrm{mol} /$ liter, which was significantly greater than that in 7 of the 11 test groups. The effect of racemic propranolol or practolol on serum FFA levels was dose related, whereas all doses of the propranolol isomers were equipotent. At the end of the experiment the mean $( \pm S E M)$ difference in serum FFA concentration between mixed blood obtained at decapitation and arterial blood from the cannula was $+54 \pm 17 \mu \mathrm{mol} /$ liter ( $n$ $=27$ ). 
Table 3. Brown fat temperature $\left({ }^{\circ} \mathrm{C}\right) 3$ - to 7-day-old rabbits nursed at $35^{\circ}$ or $25^{\circ}$ and treated with racemic, D-, or L-propranolol or

\begin{tabular}{|c|c|c|c|c|c|}
\hline & $n$ & $60 \mathrm{~min}$ & $90 \mathrm{~min}$ & $(90-30) \min$ & $(90-60) \min$ \\
\hline Thermoneutral control & 7 & $36.2 \pm 0.5^{2}$ & $36.3 \pm 0.4^{2}$ & $0.03 \pm 0.02$ & $+0.03 \pm 0.02$ \\
\hline Cold control & 8 & $35.2 \pm 0.3^{3}$ & $33.2 \pm 0.5^{3}$ & $-4.1 \pm 0.6$ & $-2.0 \pm 0.2$ \\
\hline \multicolumn{6}{|l|}{ Racemic propranolol } \\
\hline $2.25 \mathrm{mg} / \mathrm{kg}$ & 6 & $34.8 \pm 1.1^{3}$ & $30.3 \pm 0.8^{3}$ & $-7.8 \pm 0.8^{4}$ & $-4.4 \pm 0.5^{4}$ \\
\hline $5.0 \mathrm{mg} / \mathrm{kg}$ & 5 & $35.1 \pm 0.6^{3}$ & $31.2 \pm 0.8^{3}$ & $-7.2 \pm 0.8^{4}$ & $-3.9 \pm 0.4^{4}$ \\
\hline \multicolumn{6}{|l|}{ L-Propranolol } \\
\hline $1.0 \mathrm{mg} / \mathrm{kg}$ & 7 & $35.0 \pm 0.5^{3}$ & $32.9 \pm 0.7^{3}$ & $-4.9 \pm 0.7$ & $-2.1 \pm 0.3$ \\
\hline $2.25 \mathrm{mg} / \mathrm{kg}$ & 7 & $34.0 \pm 0.3^{3}$ & $31.8 \pm 0.4^{3}$ & $-5.2 \pm 0.5$ & $-2.2 \pm 0.3$ \\
\hline $5.0 \mathrm{mg} / \mathrm{kg}$ & 7 & $34.7 \pm 0.4^{3}$ & $32.5 \pm 0.3^{3}$ & $-5.3 \pm 0.3$ & $-2.3 \pm 0.5$ \\
\hline \multicolumn{6}{|l|}{ D-Propranolol } \\
\hline $2.25 \mathrm{mg} / \mathrm{kg}$ & 7 & $35.4 \pm 0.4^{3}$ & $33.4 \pm 0.4^{3}$ & $-4.4 \pm 0.4$ & $-2.0 \pm 0.4$ \\
\hline $5.0 \mathrm{mg} / \mathrm{kg}$ & 6 & $35.5 \pm 0.5^{3}$ & $32.8 \pm 0.5^{3}$ & $-5.2 \pm 0.6$ & $-2.7 \pm 0.3$ \\
\hline \multicolumn{6}{|l|}{ Practolol } \\
\hline $2.25 \mathrm{mg} / \mathrm{kg}$ & 5 & $35.5 \pm 0.9^{3}$ & $29.3 \pm 0.8^{3}$ & $-8.6 \pm 0.3$ & $-4.2 \pm 0.9^{5}$ \\
\hline $5.0 \mathrm{mg} / \mathrm{kg}$ & 5 & $33.4 \pm 1.0^{3}$ & $31.6 \pm 0.5^{3}$ & $-6.7 \pm 0.7^{5}$ & $-1.8 \pm 1.0$ \\
\hline
\end{tabular}

${ }^{1}$ Results are expressed as mean $\pm \mathrm{SEM}$. The drug was injected ip at $60 \mathrm{~min}$.

${ }^{2}$ Ambient temperature $35^{\circ}$.

${ }^{3}$ Ambient temperature $25^{\circ}$.

${ }^{4}$ Level of significance with cold control, $P<0.05$.

${ }^{5}$ Level of significance with cold control, $P<0.01$ or greater.

Table 4. Serum FFA concentration (micromoles per liter) of 3-to 7-day-old rabbits nursed at $35^{\circ}$ or $25^{\circ}$ and treated with racemic, $D$-, or

\begin{tabular}{|c|c|c|c|c|c|}
\hline & $n$ & $60 \mathrm{~min}$ & $90 \mathrm{~min}$ & $(90-30) \min$ & $(90-60) \min$ \\
\hline Thermoneutral control & 10 & $783 \pm 54^{2}$ & $822 \pm 56^{2}$ & $+51 \pm 37$ & $+39 \pm 36$ \\
\hline Cold control & 18 & $1624 \pm 129^{3}$ & $1710 \pm 135^{3}$ & $+898 \pm 119$ & $+87 \pm 26$ \\
\hline \multicolumn{6}{|l|}{ Racemic propranolol } \\
\hline $1.0 \mathrm{mg} / \mathrm{kg}$ & 10 & $759 \pm 100^{3}$ & $670 \pm 82^{3}$ & $+164 \pm 49^{4}$ & $-89 \pm 30^{4}$ \\
\hline $2.25 \mathrm{mg} / \mathrm{kg}$ & 10 & $1138 \pm 101^{3}$ & $881 \pm 78^{3}$ & $+103 \pm 45^{4}$ & $-257 \pm 46^{4}$ \\
\hline $5.0 \mathrm{mg} / \mathrm{kg}$ & 10 & $1167 \pm 104^{3}$ & $631 \pm 60^{3}$ & $-29 \pm 64^{4}$ & $-536 \pm 93^{4}$ \\
\hline \multicolumn{6}{|l|}{ L-Propranolol } \\
\hline $1.0 \mathrm{mg} / \mathrm{kg}$ & 8 & $948 \pm 77^{3}$ & $559 \pm 102^{3}$ & $+265 \pm 89^{4}$ & $-349 \pm 85^{4}$ \\
\hline $2.25 \mathrm{mg} / \mathrm{kg}$ & 8 & $1127 \pm 71^{3}$ & $707 \pm 88^{3}$ & $+96 \pm 33^{4}$ & $-420 \pm 124^{4}$ \\
\hline $5.0 \mathrm{mg} / \mathrm{kg}$ & 8 & $890 \pm 193^{3}$ & $431 \pm 69^{3}$ & $+161 \pm 64^{4}$ & $-459 \pm 133^{4}$ \\
\hline \multicolumn{6}{|l|}{ D-Propranolol } \\
\hline $1.0 \mathrm{mg} / \mathrm{kg}$ & 10 & $838 \pm 86^{3}$ & $700 \pm 87^{3}$ & $+185 \pm 73^{4}$ & $-139 \pm 60^{4}$ \\
\hline $2.25 \mathrm{mg} / \mathrm{kg}$ & 10 & $791 \pm 83^{3}$ & $630 \pm 82^{3}$ & $+126 \pm 35^{4}$ & $-160 \pm 57^{4}$ \\
\hline $5.0 \mathrm{mg} / \mathrm{kg}$ & 10 & $1081 \pm 67^{3}$ & $857 \pm 80^{3}$ & $+199 \pm 114^{4}$ & $-224 \pm 67^{4}$ \\
\hline \multicolumn{6}{|l|}{ Practolol } \\
\hline $1.0 \mathrm{mg} / \mathrm{kg}$ & 10 & $745 \pm 60^{3}$ & $719 \pm 43^{3}$ & $+149 \pm 50^{4}$ & $-26 \pm 83$ \\
\hline $2.25 \mathrm{mg} / \mathrm{kg}$ & 10 & $987 \pm 124^{3}$ & $846 \pm 104^{3}$ & $+129 \pm 67^{4}$ & $-141 \pm 70^{4}$ \\
\hline $5.0 \mathrm{mg} / \mathrm{kg}$ & 10 & $598 \pm 66^{3}$ & $730 \pm 54^{3}$ & $+48 \pm 81^{4}$ & $-228 \pm 74^{4}$ \\
\hline
\end{tabular}

${ }^{1}$ Results are expressed as mean $\pm \mathrm{SEM}$. The drug was injected ip at $60 \mathrm{~min}$.

${ }^{2}$ Ambient temperature $35^{\circ}$.

${ }^{3}$ Ambient temperature $25^{\circ}$.

${ }^{4}$ Level of significance compared with cold control: $P<0.01$.

\section{BLOOD GLUCOSE}

The mean $( \pm \mathrm{SD})$ blood glucose concentration at the time of cannulation was $5.6 \pm 1.4 \mathrm{mmol} /$ liter $(n=18)$. After $30 \mathrm{~min}$ at $35^{\circ}$ the level had risen insignificantly by $+0.3 \pm 0.2 \mathrm{mmol} / \mathrm{liter}$. However, in the thermoneutral control group the rise continued and was significant in each of the two following 30-min periods (Table 5). By comparison the rise in the cold control group on initial exposure to $25^{\circ}$ for $30 \mathrm{~min}$ was greater, being $+1.8 \pm 0.2$ $\mathrm{mmol} /$ liter $v s .+0.3 \pm 0.1 \mathrm{mmol} /$ liter in the thermoneutral control group. A further small but significant rise of $+0.3 \pm 0.1 \mathrm{mmol} / \mathrm{liter}$ occurred from 60-90 min in the cold control group. The rise in blood glucose due to cold was abolished by racemic propranolol and practolol in all doses used (Table 5). L-Propranolol significantly inhibited the rise in blood glucose from 60-90 $\mathrm{min}$ and caused a fall below the levels seen at $60 \mathrm{~min}$. D-Propranolol had no effect on blood glucose levels.

\section{DISCUSSION}

\section{CONTROL EXPERIMENTS}

The values obtained for the mean and range of observations of oxygen consumption and colonic and brown fat temperature at $35^{\circ}$ agree closely with those previously reported by us $(6,7)$ and other investigators (5). In earlier work there was little standardization of the degree or duration of cold exposure by different authors; however, the increase in oxygen consumption and fall in colonic temperature in the present experiments is similar to that previously observed by us $(6,7)$ and also by Hardman and Hull (5), who also exposed newborn rabbits of a similar mean weight to $25^{\circ}$ for 1 hr. The sustained high oxygen consumption and progressive fall in colonic and brown fat temperature after 30 and $60 \mathrm{~min}$ at $25^{\circ}$ indicate that the animals were hypothermic and, it is assumed, were responding maximally in terms of heat production. 
Table 5. Blood glucose concentration (millimoles per liter) in 3- to 7-day old rabbits nursed at $35^{\circ}$ or $25^{\circ}$ and treated with racemic, $D-$, or L-propranolol or practolol ${ }^{1}$

\begin{tabular}{|c|c|c|c|c|c|}
\hline & $n$ & $60 \mathrm{~min}$ & $90 \mathrm{~min}$ & $(90-30) \min$ & $(90-60) \min$ \\
\hline Thermoneutral control & 10 & $6.3 \pm 0.5^{2}$ & $6.8 \pm 0.6$ & $+0.8 \pm 0.1$ & $+0.5 \pm 0.1$ \\
\hline Cold control & 23 & $7.2 \pm 0.3^{3}$ & $7.5 \pm 0.3^{3}$ & $+2.2 \pm 0.2$ & $+0.3 \pm 0.1$ \\
\hline \multicolumn{6}{|l|}{ Racemic propranolol } \\
\hline $1.0 \mathrm{mg} / \mathrm{kg}$ & 10 & $5.6 \pm 0.5^{3}$ & $5.0 \pm 0.6^{3}$ & $+0.5 \pm 0.4^{4}$ & $-0.6 \pm 0.2^{4}$ \\
\hline $2.25 \mathrm{mg} / \mathrm{kg}$ & 10 & $6.2 \pm 0.5^{3}$ & $4.8 \pm 0.4^{3}$ & $+0.4 \pm 0.4^{4}$ & $-1.4 \pm 0.6^{4}$ \\
\hline $5.0 \mathrm{mg} / \mathrm{kg}$ & 10 & $7.3 \pm 0.4^{3}$ & $4.7 \pm 0.2^{3}$ & $+0.01 \pm 0.1^{4}$ & $-2.6 \pm 0.3^{4}$ \\
\hline \multicolumn{6}{|l|}{ L-Propranolol } \\
\hline $1.0 \mathrm{mg} / \mathrm{kg}$ & 7 & $9.3 \pm 0.7^{3}$ & $8.7 \pm 0.6^{3}$ & $+1.9 \pm 0.2$ & $-0.6 \pm 0.3^{5}$ \\
\hline $2.25 \mathrm{mg} / \mathrm{kg}$ & 8 & $8.6 \pm 0.5^{3}$ & $7.0 \pm 0.6^{3}$ & $+0.5 \pm 0.5^{4}$ & $-1.6 \pm 0.6^{4}$ \\
\hline $5.0 \mathrm{mg} / \mathrm{kg}$ & 8 & $9.8 \pm 0.5^{3}$ & $8.5 \pm 0.4^{3}$ & $+1.6 \pm 0.3$ & $-1.3 \pm 0.4^{4}$ \\
\hline \multicolumn{6}{|l|}{ D-Propranolol } \\
\hline $1.0 \mathrm{mg} / \mathrm{kg}$ & 10 & $6.5 \pm 0.2^{3}$ & $7.1 \pm 0.3^{3}$ & $+1.7 \pm 0.3$ & $+0.4 \pm 0.1$ \\
\hline $2.25 \mathrm{mg} / \mathrm{kg}$ & 10 & $6.8 \pm 0.6^{3}$ & $7.1 \pm 0.6^{3}$ & $+2.0 \pm 0.4$ & $+0.2 \pm 0.3$ \\
\hline $5.0 \mathrm{mg} / \mathrm{kg}$ & 10 & $6.1 \pm 0.2^{3}$ & $6.1 \pm 0.4^{3}$ & $+1.5 \pm 0.3^{5}$ & $-0.02 \pm 0.6$ \\
\hline \multicolumn{6}{|l|}{ Practolol } \\
\hline $1.0 \mathrm{mg} / \mathrm{kg}$ & 10 & $7.8 \pm 0.5^{3}$ & $6.9 \pm 0.5^{3}$ & $+0.01 \pm 0.3^{4}$ & $-0.9 \pm 0.3^{4}$ \\
\hline $2.25 \mathrm{mg} / \mathrm{kg}$ & 10 & $6.7 \pm 0.4^{3}$ & $5.9 \pm 0.2^{3}$ & $+0.3 \pm 0.2^{4}$ & $-0.8 \pm 0.3^{4}$ \\
\hline $5.0 \mathrm{mg} / \mathrm{kg}$ & 10 & $7.7 \pm 0.3^{3}$ & $6.6 \pm 0.2^{3}$ & $+0.3 \pm 0.3^{4}$ & $-1.1 \pm 0.3^{4}$ \\
\hline
\end{tabular}

${ }^{1}$ Results are expressed as mean \pm SEM. The drug was injected ip at $60 \mathrm{~min}$.

${ }^{2}$ Ambient temperature $35^{\circ}$.

${ }^{3}$ Ambient temperature $25^{\circ}$

${ }^{4}$ Level of significance compared with cold control: $P<0.01$.

${ }^{5}$ Level of significance compared with cold control: $P<0.05$.

The carotid arterial cannulation for blood sampling was essential to permit comparison of values from the same animal, but had the disadvantage of general anesthesia and operative manipulation, both of which are known to raise blood glucose and plasma FFA levels. In fact the progressive rise in the mean blood glucose level of the thermoneutral control group ended at a value which was not significantly different from that found in another group of rabbits, placed alone in chambers at $35^{\circ}$ for $3.5 \mathrm{hr}$, studied earlier by the same workers (2). Clearly the handling and isolation of a rabbit pup is sufficient stimulus to cause a rise in blood glucose. Anesthesia and operation do not affect blood glucose levels significantly in addition to this. Insignificant changes took place in the mean serum FFA concentration of the thermoneutral control group which were similar to those of the unoperated rabbits referred to above. Cold exposure caused a dramatic rise in serum FFA levels, which has been documented many times, and a rise in blood glucose that was greater than that due to handling, isolation, and anesthesia. These changes were the yardstick against which the effects of the drugs were measured.

\section{DRUG-TREATED ANIMALS}

Racemic propranolol and practolol, which is also a racemic compound with molecular weight and pharmacologic properties like those of propranolol, had similar effects in that all doses significantly reduced or abolished the changes in oxygen consumption, serum FFA, and blood glucose caused by cold. These findings are in keeping with our earlier observations that racemic propranolol can prevent catecholamine-induced hyperglycemia in a thermoneutral environment (8) as well as cold-induced increase in glycogenolysis and lipolysis (11). The effect on oxygen consumption and serum FFA levels was dose related in that a weaker action was seen with $1 \mathrm{mg} / \mathrm{kg}$ than with 2.25 or $5.0 \mathrm{mg} / \mathrm{kg}$, but no dose dependence was apparent in the effect on blood glucose levels. Both drugs caused a significantly greater fall in brown fat temperature than was caused by cold alone, but this was not reflected in colonic temperature, which although lower in the drug-treated animals, was not significantly less than the level in the control group.

The isomers of propranolol were studied in an attempt to clarify the mechanism by which the racemic drug might influence the response to cold. D-Propranolol is thought to have a membrane- stabilizing action but low $\beta$-blocking potency (21), whereas Lpropranolol has both a $\beta$-blocking and membrane-stabilizing action (3). The fall in blood glucose and serum FFA caused by $\mathrm{L}-$ propranolol confirms our earlier findings at both $35^{\circ}$ and $25^{\circ}(2$, 11 , and may be explained on the basis of the $\beta$-blocking action. The effect of $\mathrm{D}$-propranolol in lowering the serum FFA significantly at Ta $25^{\circ}$ was compatible with the result of earlier work (2) in which a small insignificant reduction was observed when the dose of $1 \mathrm{mg} / \mathrm{kg}$ was employed. It is not possible to propose a mechanism of action, however, since at $35^{\circ}, 1 \mathrm{mg} / \mathrm{kg}$ D-propranolol caused a rise in mean serum FFA and blood glucose concentration (2). It is noteworthy that neither isomer even at the highest dose had a significant effect on oxygen consumption or brown fat temperature, whereas when acting together at half that dose in the form of the racemer, there was a profound effect.

\section{GENERAL}

The present experiments have demonstrated clearly that the $\beta$ blocker drugs propranolol and practolol can abolish the ability of newborn rabbits to respond to a cold stress. Despite the use of an animal model these findings have direct clinical relevance since infants are born who have been exposed to $\beta$ blockers in utero or who may require such drugs as treatment in the neonatal period. The dosage range used in the animal experiments was defined in earlier experiments on the basis of cardiovascular effects (2). Although it was much greater than that recommended for parenteral administration to the human infant $(0.02-0.1 \mathrm{mg} / \mathrm{kg} / \mathrm{dose})$ it was comparable to that recommended for oral therapy $(0.5-1.0$ $\mathrm{mg} / \mathrm{kg} /$ dose). Inasmuch as little is known about accumulation of maternally administered $\beta$ blockers in the human fetus or about their pharmacology in the newborn, we consider that our findings should be taken as a warning that such infants may respond subnormally to cold stress and show other abnormalities of metabolic homeostasis. If this risk is appreciated, appropriate care and precautions can be taken.

\section{REFERENCES AND NOTES}

1. Barnes, A. B.: Chronic propranolol administration during pregnancy. J. Reprod. Med., 5: 79 (1970).

2. Cser, A., Girard, J., Goode, M., Leach, F. N., Assan, R., and Milner, R. D. G.: 
Effects of racemic.dextro, laevo-propranolol and isoxuprine on the metabolic and endocrine response to cold in the newborn rabbit. Eur. J. Clin. Invest., In press.

3. Gibson, D. G.: Pharmacodynamic properties of adrenergic receptor blocking drugs in man. Drugs, 7: 8 (1974).

4. Gladstone, G. R., Hordof, A., and Gersony, W. M.: Propranolol administration during pregnancy: Effects on the fetus. J. Pediat., 86: 962 (1975).

5. Hardman, M. J., and Hull, D.: The effects of age and environmental temperature on the blood concentrations of glucose, free fatty acids and glycerol in newborn rabbits. J. Physiol. (London), 201: 685 (1969).

6. Heim, T., and Hull, D.: The blood flow and oxygen consumption of brown adipose tissue in the newborn rabbit. J. Physiol. (London), 186: 42 (1966).

7. Heim, T., and Hull, D.: The effect of propranolol on the calorigenic response in brown adipose tissue of newborn rabbits to catecholamines, glucagon, corticotrophin and cold exposure. J. Physiol. (London), 187: 271 (1966).

8. Heim, T., and Hull, D.: Propranolol and hypoglycaemia. Lancet, 1: 396 (1967).

9. Heim, T., and Salamon, I.: Zartrendszeru keszulek kis allatok oxygenfogyasztasanak percenkenti meghatarozasara. Kiserl. Orvostud., 23: 80 (1971).

10. Heim, T., Dober, I., Jaszai, V., Cser, A., and Varga, F.: exuect of beta-adrenergic receptor blockers on cold induced thermogenesis in the newborn rabbit. Pediat. Res., 8: 911 (1974).

11. Heim, T., Dober, I., Jaszai, V., Cser, A., and Varga, F.: Effects of three adrenergic receptor blockers on cold thermogenesis in the newborn rabbit. In: L. Jansky: Depressed Metabolism and Cold Induced Thermogenesis. Academia Monograph Prague, 1977 (Monograph chapter, in press).

12. Heim, T., Dober, I., Galamb, M., and Jaszai, V.: Drug effects on thermoregulation of the neonatal rabbit. In: K. Cooper. P. Lomax, and E. Schonbaum: Drugs, Biogenic amines and Body Temperature, pp. 176-178 (Karger, Basel, 1977).

13. Hull. D.: Pronethalol and the oxygen consumption of new-born rabbits. $J$. Physiol. (Lond.), 173: 13 (1964).

14. Hultman. E.: Rapid specific method for determination of aldosaccharides in body fluids. Nature (London), 183: 108 (1959)

15. Mahon, W. A., Reid, D. W. J., and Day, R. A.: The in vivo effects of beta adrenergic stimulation and blockade on the human uterus at term. J. Pharmacol. Exp. Ther., 156: 178 (1967).

16. Mitrani, A., Oettingern, M., Abinades, E. G., Scharf, M., and Klein, A.: Use of propranolol in dysfunctional labour. Brit. J. Obstet. Gynecol., 82: 651, (1975).

17. Novak, M.: Colorimetric ultramicromethod for the determination of free fatty acids. J. Lipid Res., 6: 431 (1965).

18. Reed, R. L., Cheney, C. B., Flaron, R. E., Hook, R., and Henre, F.: Propranolol therapy throughout pregnancy: A case report. Anesthes. Analges. Curr. Res., 53: 214 (1974).

19. Scopes, J. W., and Tizard, J. P. M.: The effect of intravenous noradrenaline on the oxygen consumption of newborn mammals. J. Physiol. (London), 165: 305 (1963).

20. Truelove, J. F., Van Petten, G. R., and Willes, R. F.: Action of several betaadrenoreceptor blocking drugs on the pregnant sheep and foetus. Brit. $J$. Pharmacol., 44: 161 (1973).

21. Williams, W. M. W.: Electrophysiological and other actions of oxprenalol and its parasubstituted isomer. In: D. M. Burley, J. H. Frier, R. K. Randel, and S. H. Taylor: New Perspective in Beta-blockade, p. 73 (Ciba Laboratories, Horhsam, 1973).

22. $\beta$ Blockers were kindly donated by Dr. John A. Waycott, Medical Division, Imperial Chemical Industries Ltd., Macclesfield, Cheshire, England.

23. I. Dober received a Postdoctoral Fellowship from the Hungarian Ministry of Health during the period of this study.

24. We are grateful to Professor F. Varga and Dr. A. Cser for their encouragement and help.

25. Requests for reprints should be addressed to: Professor R. D. G. Milner, Department of Paediatrics, Children's Hospital, Sheffield S10 2TH (England).

26. Received for publication October 12, 1977.

27. Accepted for publication January 27, 1978. 